\title{
Phosphorus removal from secondary sewage and septage using sand media amended with biochar in constructed wetland mesocosms
}

\author{
P. de Rozari a,b,*, M. Greenway ${ }^{\text {a }}$, A. El Hanandeh ${ }^{c}$ \\ ${ }^{a}$ Griffith School of Engineering, Griffith University, Environmental Futures Research Institute Griffith Sciences, Nathan, Brisbane, Australia \\ ${ }^{\mathrm{b}}$ Department of Chemistry, Faculty of Science and Engineering, Nusa Cendana University, Kupang, Indonesia \\ c Griffith School of Engineering, Griffith University, Nathan, Brisbane, Australia
}

\section{H I G H L I G H T S}

- Phosphorus removal efficiency were inversely related to the biochar content of media.

- Sand amended with biochar is less effective in removing $P$ than pure sand.

- Presence of biochar encouraged microbial P activity.

- The most microbial P activities occurred in the upper $20 \mathrm{~cm}$ of media.

- Total biomass $P$ in pure sand was higher than sand amended with biochar.

\section{G R A P H I C A L A B S T R A C T}

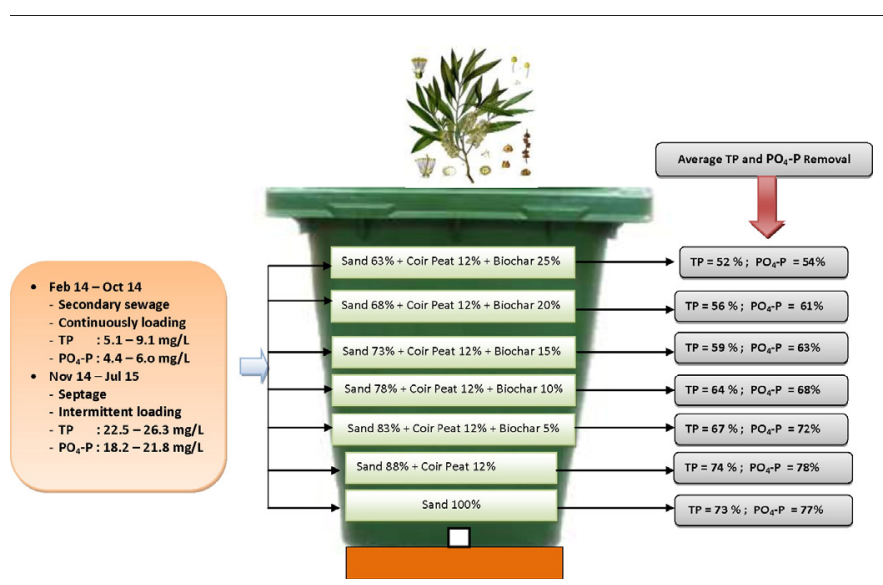

\section{A B S T R A C T}

To improve the performance efficiency of subsurface constructed wetlands (CWs), a variety of media have been tested. Recently, there has been a rising interest in biochar. This research aims to develop the effectiveness of sand media amended with biochar and two plants species (Melaleuca quinquenervia and Cymbopogon citratus) in removing phosphorus from sewage effluent in CWs. The experimental design consisted of vertical flow (VF) mesocosms with seven media treatments based on the proportions of biochar in the sand media which ranged from 0 to $25 \%$ by volume. During the first 8 months, the mesocosms were loaded with secondary clarified wastewater (SCW) then septage was used for the remaining 8 months. Inflow and outflow were monitored for total phosphorus (TP) and $\mathrm{PO}_{4}$-P. Plants were harvested at the end of the experiment and TP biomass was determined. Removal efficiencies of TP in the mesocosms loaded with SCW and septage ranged from 42 to $91 \%$ and 30 to $83 \%$, respectively. Removal efficiencies of $\mathrm{PO}_{4}-\mathrm{P}$ ranged from 43 to $-92 \%$ and 35 to $85 \%$ for SCW and septage, respectively. The results revealed that the sand media performed better than the biochar-amended media; increasing the proportion of biochar in the media decreased removal efficiency of phosphorus. However, after flushing due to major rain event, there was no significant difference between sand and sand augmented with $20 \%$ biochar.

Abbreviation: AEC, anion exchange capacity; BOD, biological oxygen demand; C, carbon; CEC, cation exchange capacity; CP, coir peat; CW, constructed wetland; DSTC, digested sugar

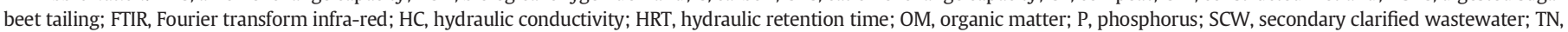
total nitrogen; TP, total phosphorus; TSS, total suspended solids; VF, vertical flow; VFCW, vertical flow constructed wetlands; WTR, water treatment residuals.

* Corresponding author.

E-mail addresses: phderozari@yahoo.com, philiphi.derozari@griffithuni.edu (P. de Rozari), m.greenway@griffith.edu.au (M. Greenway), a.elhanandeh@griffith.edu.au (A. El Hanandeh). 
Secondary sewage

Septage
Total plant P ranged from $1.75 \mathrm{~g}$ in the $20 \%$ biochar mesocosm to $2.10 \mathrm{~g}$ in the sand only mesocosm. Plant uptake of $\mathrm{P}$, at least in part, may be accredited for the better P removal efficiency in the sand media compared to the biochar-amended media.

(c) 2016 Elsevier B.V. All rights reserved.

\section{Introduction}

Eutrophication of fresh water bodies is one of the main problems facing aquatic ecosystems. In developing countries, approximately $75 \%$ of domestic wastewater is released to the environment without treatment (Kurniadie 2011, Westholm 2006). Ayaz et al. (2012) reported that eutrophication in receiving water bodies may occur when phosphorus concentrations are $>6 \mathrm{mg} / \mathrm{L}$. Therefore, proper treatment to remove phosphorus from domestic wastewater to achieve the admissible level for natural systems is needed.

Constructed wetlands (CWs) are easy to implement ecotechnologies which have been proven as efficient technologies for wastewater treatment. Constructed wetlands are also known for offering low cost, simple operation and low maintenance wastewater treatment solution (Kadlec and Wallace 2008). Although, CW technologies are efficient in removing biological oxygen demand (BOD) and total suspended solids (TSS) from wastewater (Abou-Elela et al. 2013, De Rozari et al. 2015), phosphorus removal is still a challenge (Ayaz et al. 2012).

Different materials have been used as a media to enhance and enable long term phosphorus removal in CWs; for example: (1) natural material such as zeolites, dolomite, gravels, sands, limestone and apatite, (2) man-made products, such as filtralite, alunite, norlite, and (3) by products such as red mud, fly ash, and slag (Vohla et al. 2011). Arias et al. (2001) stated that sand mainly would be effective in removing phosphorus only for a few months in full scale systems. However, Vohla et al. (2011) reported long term purification of phosphorus utilizing sand media. Lucas and Greenway (2010) found that sand amended with red mud and water treatment residuals improved long term phosphorus removal from secondary effluent.

Lately, there has been a rising interest in biochar as a potential alternative media for wastewater treatment. Biochar is carbon-rich product obtained by the thermochemical decomposition of biomass in the absence of oxygen or under depleted oxygen conditions (Hossain et al. 2011, Manya 2012). Based on laboratory experiment, Yao et al. (2011) reported that biochar prepared at $600{ }^{\circ} \mathrm{C}$ from digested sugar beet tailing (DSTC) had better phosphate removal ability (73\%) than activated carbon prepared from coconut shell. Batch sorption experiment with different shaking times $(1,8,24 \mathrm{~h}$ and 1 week) conducted by Sarkhot et al. (2013) showed that hardwood-biochar prepared via slow pyrolysis (at $300{ }^{\circ} \mathrm{C}$ and residence time $8-12 \mathrm{~h}$ ) can absorb $50 \%$ and $96 \%$ of $\mathrm{PO}_{4}^{3-}$ solution from manure and synthetic solution, respectively. Chintala et al. (2014) compared P-sorption efficiency of different types of biochar prepared in fast pyrolysis process at $650{ }^{\circ} \mathrm{C}$ and reported that the P-sorption efficiency of biochar of corn stover (Zea mays L.) and switchgrass (Panicum virgatum L.) were $79 \%$ and $76 \%$, respectively.
These findings suggest that biochar may enhance phosphorus removal from wastewater and may provide a low cost media amendment for improving the performance of CWs. Limited literature is found about the effect of biochar on the performance of constructed wetlands to remove phosphorus from wastewater (Gupta et al. 2015). However, these studies were conducted in controlled laboratory scale environment and mostly using synthetic wastewater. Therefore, the objective of this study was to investigate the efficiency of biochar as media amendment in VFCWs for phosphorus removal at mesocosm scale subjected to natural environmental conditions. To the best of the authors' knowledge this is the first study conducted at mesocosm scale to investigate the effect of sand media amendment with biochar on the performance of constructed wetland to remove phosphorus from actual secondary treated wastewater and raw septage under natural environment conditions.

\section{Methods}

\subsection{Experimental design}

The experiments were carried out from November 2013 through July 2015 at the Loganholme Water Pollution Control Centre, $40 \mathrm{~km}$ south of Brisbane in South East Queensland. Seven treatments with different biochar content were setup (Table 1). All treatments were triplicated. In total, there were 21 vertical flow (VF) mesocosm bins made of plastic containers measuring $0.5 \mathrm{~m} \times 0.5 \mathrm{~m} \times 0.98 \mathrm{~m}$ (240-1). Fig. 1 shows a schematic diagram of the mesocosm setup. More detailed description of the experimental setup can be found in de Rozari et al. (2015).

The mesocoms were planted with one Melaleuca tree ( $M$. quinquenervia) and one lemongrass (C. citratus) each. The selection of Melaleuca was based on their (1) ability to tolerate inundation; (2) high potential biomass sink for nutrients; (3) high rates of litter fall but slow decomposition; and (4) endurance in extreme conditions i.e. salinity, alkalinity, acidity (Bolton and Greenway 1997); Lemongrass (C. citratus) is a perennial grass which is widely cultivated in tropical countries and was selected due to its effectiveness to reduce suspended solids (Wanyama et al. 2012) and its economical value particularly for traditional medicine (Ekpenyong et al. 2015).

The experiment was conducted in three phases over a period of 21 months between November 2013 and July 2015 as shown in Table 2. The wastewater was obtained from Loganholme Water Pollution Control Centre and stored in $5000 \mathrm{~L}$ tanks. Each tank distributed the effluent to seven treatment mesocosms and was topped up with new effluents every month.

Table 1

Percentage and characteristic of media in the mesocosm system.

\begin{tabular}{|c|c|c|c|c|c|c|c|c|}
\hline \multirow[t]{2}{*}{ Media } & \multicolumn{3}{|c|}{ Percentage of media (\%) } & \multirow[t]{2}{*}{$\mathrm{pH}$} & \multirow[t]{2}{*}{$\% \mathrm{OM}$} & \multirow{2}{*}{$\begin{array}{l}\text { CEC } \\
\mathrm{cmol}(+) / \mathrm{kg}\end{array}$} & \multirow{2}{*}{$\begin{array}{l}\mathrm{AEC} \\
\mathrm{cmol}(-) / \mathrm{kg}\end{array}$} & \multirow{2}{*}{$\begin{array}{l}\text { Range of } \mathrm{HC} \\
(\mathrm{cm} / \mathrm{h})\end{array}$} \\
\hline & Sand & Biochar & $\overline{\mathrm{CP}}$ & & & & & \\
\hline S100 & 100 & - & - & $6.79 \pm 0.02$ & $0.36 \pm 0.02$ & $5.73 \pm 0.54$ & $1.09 \pm 0.05$ & $94-108$ \\
\hline SCP & 88 & - & 12 & $6.74 \pm 0.01$ & $0.63 \pm 0.08$ & $5.90 \pm 0.26$ & - & $93-103$ \\
\hline BC5 & 83 & 5 & 12 & $6.81 \pm 0.01$ & $1.28 \pm 0.07$ & $6.85 \pm 0.54$ & $1.31 \pm 0.04$ & $82-87$ \\
\hline BC10 & 78 & 10 & 12 & $6.88 \pm 0.01$ & $2.21 \pm 0.08$ & $7.55 \pm 0.30$ & $1.40 \pm 0.11$ & $81-87$ \\
\hline BC15 & 73 & 15 & 12 & $6.99 \pm 0.01$ & $3.37 \pm 0.11$ & $8.37 \pm 0.27$ & $1.43 \pm 0.05$ & $67-76$ \\
\hline BC20 & 68 & 20 & 12 & $7.06 \pm 0.02$ & $4.52 \pm 0.05$ & $9.23 \pm 0.35$ & $1.51 \pm 0.07$ & $63-71$ \\
\hline $\mathrm{BC} 25$ & 63 & 25 & 12 & $7.19 \pm 0.02$ & $5.55 \pm 0.21$ & $10.21 \pm 0.13$ & $1.62 \pm 0.17$ & $61-66$ \\
\hline
\end{tabular}

The hydraulic conductivity (HC) was measured on February, August 2014 and March 2015 


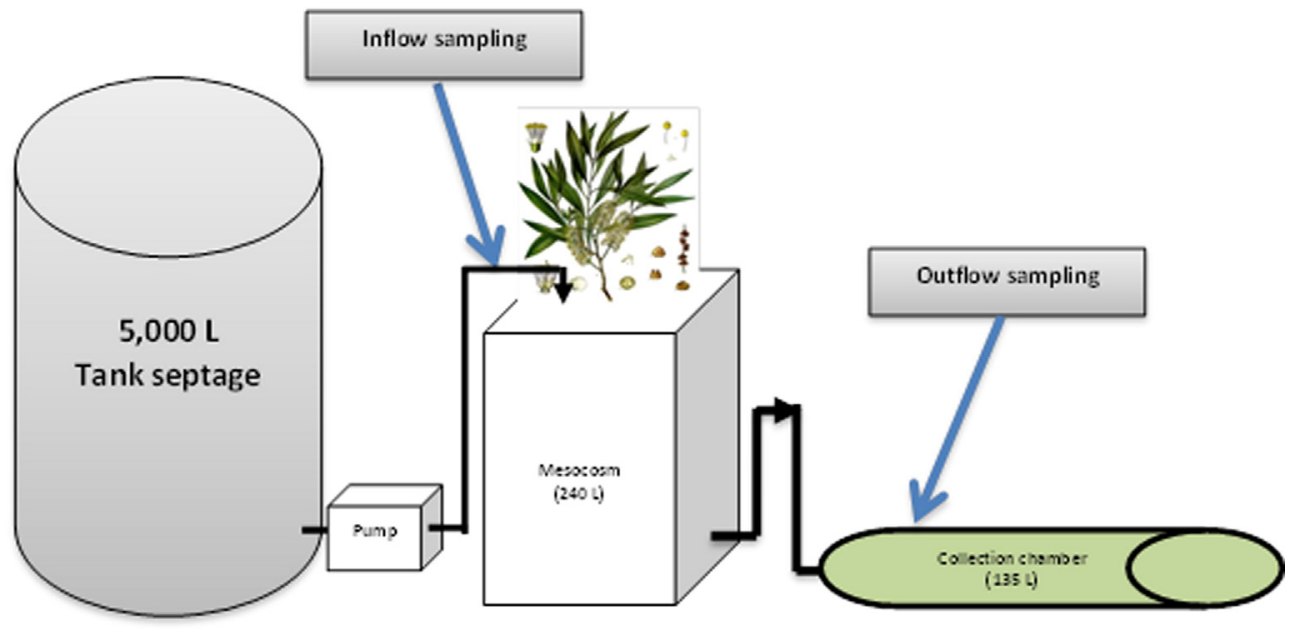

Fig. 1. Schematic diagram of the mesocosm setup.

\subsubsection{Water sample collection and analysis}

Water samples (inflow and outflow) were collected every two weeks for the first four months (March-June 2014) and then monthly from August 2014 to July 2015. The inflows were collected from the inlet hose which is connected to the storage tank and the outflows were collected from $135 \mathrm{~L}$ collection chamber connected to the mesocosm which is cable of storing up to two weeks of the treated outflow.

All the analysis of TP and $\mathrm{PO}_{4}-\mathrm{P}$ were conducted according to standard methods for the examination of water and wastewater (APHA 2005). After collection, the samples were refrigerated at $4{ }^{\circ} \mathrm{C}$ for transport and temporary storage (maximum of $24 \mathrm{~h}$ ) and then frozen until analysed. To determine $\mathrm{PO}_{4}-\mathrm{P}$, the samples were filtered using $0.45 \mu \mathrm{m}$ millipore filters. The filtered solutions were then analysed using colorimetric methods with a Discrete Chemistry Analyser (Westco Smartchem 200, Danbury CT, USA). To determine TP, the standards and samples were first digested using standard persulphate digests and analysed using colorimetric methods based on procedure number 4500-P B and E (APHA 2005).

\subsubsection{Microbial $P$}

Microbial phosphorus was determined in soil samples collected in August 2014. The samples were taken from three different depths (0$10 ; 10-20$; and $20-30 \mathrm{~cm}$ ). Determination of microbial P was carried out by bacterial fumigation extraction method (Brookes et al. 1982). In this method, the cell membranes of soil organisms are destroyed by fumigation processes with chloroform $\left(\mathrm{CHCl}_{3}\right)$. This causes the cell contents to leak into the soil. The soil $\mathrm{P}$ content in non-fumigated samples (leachable P) was also measured. The P was extracted from fumigated and non-fumigated soil samples and then the samples were analysed with the ascorbic acid molybdenum colorimetric methods. The microbial biomass $P$ was determined by calculating the difference between the amount of inorganic P extracted according to the following formula (Brookes et al. 1982).

Microbial $P=($ Microbial $P+$ leachable $P)-($ leachable $P)$

\subsubsection{Plant samples}

The plants in the bins from four treatments (BC5, BC10, BC15 and BC25) were harvested in March 2015. The remaining three bins (S100, SCP and BC20) were harvested in July 2015. The selection of the harvesting time was based on the performance of each treatment in removing pollutants. The sand media with high proportion of biochar (BC20 and $\mathrm{BC} 25$ ) were more effective in removing $\mathrm{BOD}_{5}, \mathrm{TSS}$, and coliforms, TN, $\mathrm{NH}_{4}-\mathrm{N}$ and $\mathrm{NO}_{\mathrm{x}}$ than other biochar amended media and therefore were left for further investigation. Pure sand media (S100 and SCP) were more effective in removing TP and $\mathrm{PO}_{4}-\mathrm{P}$. Since there was no significant difference between the sand media amended with $20 \%$ of biochar (BC20) and the sand media amended with $25 \%$ of biochar (BC25) in removing the pollutants, $\mathrm{BC} 20$ was selected to be harvested in July 2015 together with pure sand media (S100 and SCP). The destructive harvest was conducted to determine biomass and TP accumulation in the plants. The Melaleuca trees were separated into stems, branches, leaves, barks and roots while for lemongrass plants were separated into shoots, rhizome and roots. These samples were oven dried for $48 \mathrm{~h}$ at $70{ }^{\circ} \mathrm{C}$ to obtain constant dry weight and ground using grinding mill. Total biomass $P$ was determined by measuring the amount of TP in each part of the plants. Samples were digested using micro digester $\left(\mathrm{HNO}_{3}-\mathrm{H}_{2} \mathrm{O}_{2}\right)$ ((Matejovic and Durackova 1994) and then quantified using ascorbic acid molybdenum colorimetric methods (APHA 2005).

\subsection{Statistical and data analysis}

The experimental results were statistically analysed using SPSS 21 software. The performance of each treatment was carried out by calculating water (inflow and outflow concentration) of $\mathrm{TP}$ and $\mathrm{PO}_{4}$-P. Percentage removal efficiency was calculated as $\% \mathrm{R}=\frac{C_{\text {in }}-C_{\text {ef }}}{C_{\text {in }}} \times 100 \%$ where $\mathrm{C}_{i n}$ and $\mathrm{C}_{\text {ef }}$ are inflow and outflow of TP and $\mathrm{PO}_{4}-\mathrm{P}$ concentration. Mean and standard deviation for each dataset were calculated. One-way ANOVA analyses were applied to test for differences among treatments for each parameter. Tukey HSD post-hoc tests were then carried out to determine which treatments were significantly different. In all cases, significant level $(\alpha=0.05)$ was used.

Table 2

Summary of the experiment phases.

\begin{tabular}{|c|c|c|c|c|c|c|}
\hline Phase & Date & Purpose & Wastewater type & Loading condition & $\begin{array}{l}\mathrm{PO}_{4} \text {-P Loading } \\
\text { (mg/day) }\end{array}$ & $\begin{array}{l}\text { TP Loading } \\
\text { (mg/day) }\end{array}$ \\
\hline Phase 1 & $11 / 13-1 / 14$ & Establishment & Tertiary treated wastewater & Drip irrigation & $0.03-0.04$ & $0.04-0.05$ \\
\hline Phase 2 & $2 / 14-10 / 14$ & Investigate P removal from SCW & SCW & Drip irrigation & $0.07-0.09$ & $0.08-0.14$ \\
\hline Phase 3 & $11 / 14-7 / 15$ & Investigate $\mathrm{P}$ removal from septage & Septage & Intermittent loading & $0.18-0.22$ & $0.22-0.26$ \\
\hline
\end{tabular}


Table 3

The mean and standard deviation $(x \pm \mathrm{SD})$ of inflow concentrations of $\mathrm{TP}$ and $\mathrm{PO}_{4}-\mathrm{P}(\mathrm{mg} / \mathrm{L})$ and $\%$ of $\mathrm{PO}_{4}-\mathrm{P}$ in SCW and septage.

\begin{tabular}{|c|c|c|c|c|c|}
\hline \multirow[t]{2}{*}{ Date } & \multicolumn{2}{|l|}{ SCW } & \multirow[t]{2}{*}{ Date } & \multicolumn{2}{|l|}{ Septage } \\
\hline & $\mathrm{TP}$ & $\mathrm{PO}_{4}-\mathrm{P}$ & & $\mathrm{TP}$ & $\mathrm{PO}_{4}-\mathrm{P}$ \\
\hline 12, Mar. 14 & $7.5 \pm 2.5$ & $4.7 \pm 0.7$ & 4, Nov. 14 & $25.2 \pm 2.4$ & $21.8 \pm 1.2$ \\
\hline 27, Mar. 14 & $9.1 \pm 0.2$ & $4.4 \pm 0.3$ & 7, Dec. 14 & $25.3 \pm 1.8$ & $21.3 \pm 1.3$ \\
\hline 14, Apr. 14 & $7.3 \pm 0.4$ & $5.0 \pm 0.2$ & 5, Jan. 15 & $25.7 \pm 2.0$ & $20.2 \pm 1.5$ \\
\hline 3, May 14 & $5.1 \pm 0.2$ & $5.0 \pm 0.3$ & 5, Feb. 15 & $22.8 \pm 1.8$ & $18.8 \pm 1.4$ \\
\hline 23, May 14 & $6.0 \pm 0.2$ & $4.7 \pm 0.1$ & 4, Mar. 15 & $26.3 \pm 2.2$ & $20.1 \pm 1.9$ \\
\hline 6 , June 14 & $5.5 \pm 0.4$ & $5.1 \pm 0.2$ & 15, Apr. 15 & $26.2 \pm 0.9$ & $21.8 \pm 0.4$ \\
\hline 2, Aug. 14 & $5.6 \pm 0.3$ & $4.8 \pm 0.2$ & 10, May 15 & $23.2 \pm 1.5$ & $19.7 \pm 1.4$ \\
\hline 5, Sept. 14 & $6.4 \pm 0.9$ & $5.7 \pm 0.3$ & 7, Jun. 15 & $23.3 \pm 0.5$ & $18.8 \pm 0.6$ \\
\hline 5, Oct. 14 & $6.4 \pm 0.1$ & $6.0 \pm 0.1$ & 9, Jul. 15 & $22.5 \pm 1.6$ & $18.2 \pm 0.9$ \\
\hline
\end{tabular}

For microbial $\mathrm{P}$, the mean and standard deviation of each treatment in each depth $(0-10 ; 10-20 ; 20-30 \mathrm{~cm})$ were determined. Significant difference of microbial $\mathrm{P}$ abundance in each depth among the different treatments was assessed using One-way ANOVA test. In addition, the One-way ANOVA test was used to determine the significant difference of microbial $P$ of each treatment among different depth. The Tukey post-hoc tests $(\alpha=0.05)$ was conducted to determine the significant difference of microbial $\mathrm{P}$ among the subsets. The significant differences of plant biomass P among 4 treatments harvested in March (BC5; BC10;
BC15 and BC25) and July 2015 (S100; SCP and BC20) were also assessed using One-way ANOVA.

\section{Results and discussion}

The results of the experiment are presented in the following sections. First, the wastewater characteristics are introduced. Second, the performance of the mesocosms for removing phosphorus from secondary clarified wastewater and septage are presented. Third, the

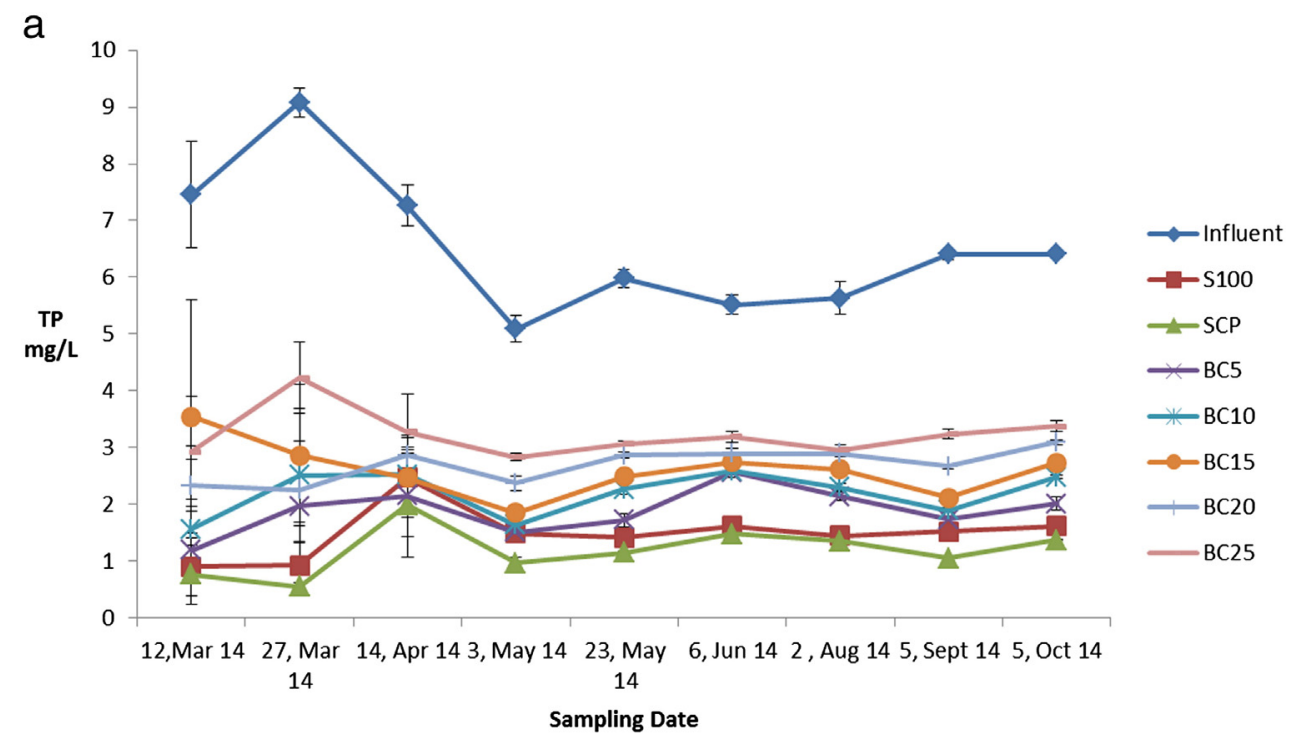

b

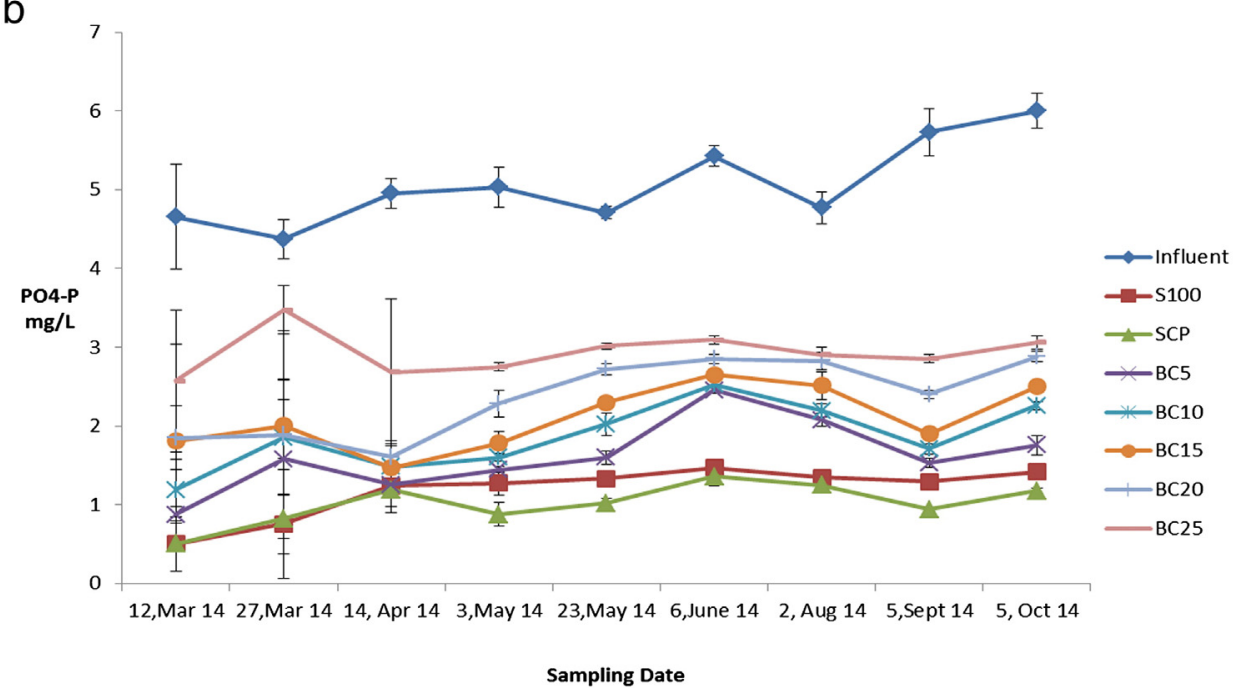

Fig. 2. TP and $\mathrm{PO}_{4}-\mathrm{P}$ concentrations ( $\mathrm{mg} / \mathrm{L}$ ) in $\mathrm{VF}$ mesocosms with seven different media loaded continuously with SCW (saturated media). 
Table 4

Significant differences of TP and $\mathrm{PO}_{4}$-P loaded with secondary clarified wastewater among the treatments $(\alpha<0.05)$.

\begin{tabular}{|c|c|c|c|c|c|c|c|}
\hline & $\mathrm{S} 100$ & SCP & BC5 & BC10 & BC15 & BC20 & BC25 \\
\hline S100 & - & - & $\mathrm{x}$ & $x+$ & $x+$ & $x+$ & $x+$ \\
\hline SCP & - & - & $x+$ & $x+$ & $x+$ & $x+$ & $x+$ \\
\hline BC5 & $\mathrm{x}$ & $x+$ & - & $x+$ & $\mathrm{x}$ & $x+$ & $x+$ \\
\hline $\mathrm{BC} 10$ & $x+$ & $x+$ & $x+$ & - & - & $x+$ & $x+$ \\
\hline BC15 & $x+$ & $x+$ & $\mathrm{x}$ & - & - & $x+$ & $x+$ \\
\hline BC20 & $x+$ & $x+$ & $x+$ & $x+$ & $x+$ & - & - \\
\hline BC25 & $x+$ & $x+$ & $x+$ & $x+$ & $\mathrm{x}$ & - & - \\
\hline
\end{tabular}

$\mathrm{x}$ : significant difference of TP $(\alpha<0.05)$.

+ : significant difference of $\mathrm{PO}_{4}-\mathrm{P}(\alpha<0.05)$.

- : No significant differences.

microbial-P activity in the media and their role in phosphorus removal are presented. Finally, the role of plants in phosphorus removal in mesocosms is presented. Discussion of the results is presented in each section where relevant.

\subsection{Wastewater characteristics}

The inflow of BOD, TSS, TN and $\mathrm{pH}$ of the SCW were in the ranges of 121-247 mg/L, 26-52 mg/L, 2.9-4.0 mg/L and 7.84-8.26, respectively. For septage, the inflow of BOD, TSS, TN and pH ranged from 399 to
$488 \mathrm{mg} / \mathrm{L}, 240-367 \mathrm{mg} / \mathrm{L}, 101-131 \mathrm{mg} / \mathrm{L}$ and 8.14-8.34, respectively. The inflow of TP and $\mathrm{PO}_{4}-\mathrm{P}$ concentrations are shown in Table 3. $\mathrm{PO}_{4}$ P contributed $76.4-86.4 \%$ of TP in the septage and $67.4-98.9 \%$ of TP in the SCW.

\subsection{TP and $\mathrm{PO}_{4}-\mathrm{P}$ secondary clarified wastewater (March-October 2014)}

The mean outflows of TP and $\mathrm{PO}_{4}-\mathrm{P}$ from SCW ranged from $0.56 \mathrm{mg} /$ $\mathrm{L}-4.23 \mathrm{mg} / \mathrm{L}$ and $0.51 \mathrm{mg} / \mathrm{L}-3.48 \mathrm{mg} / \mathrm{L}$, respectively (Fig. 2). As shown in Fig. 2, outflow concentrations of TP and $\mathrm{PO}_{4}$-P from sand media without

a

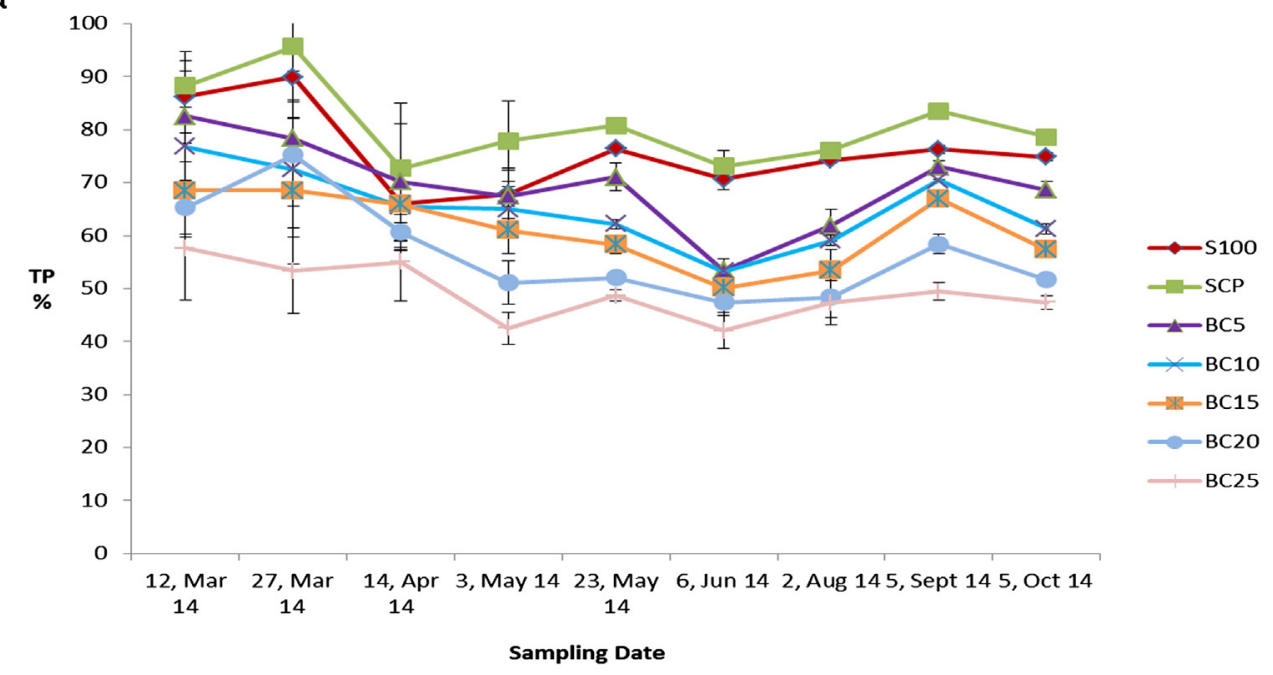

b

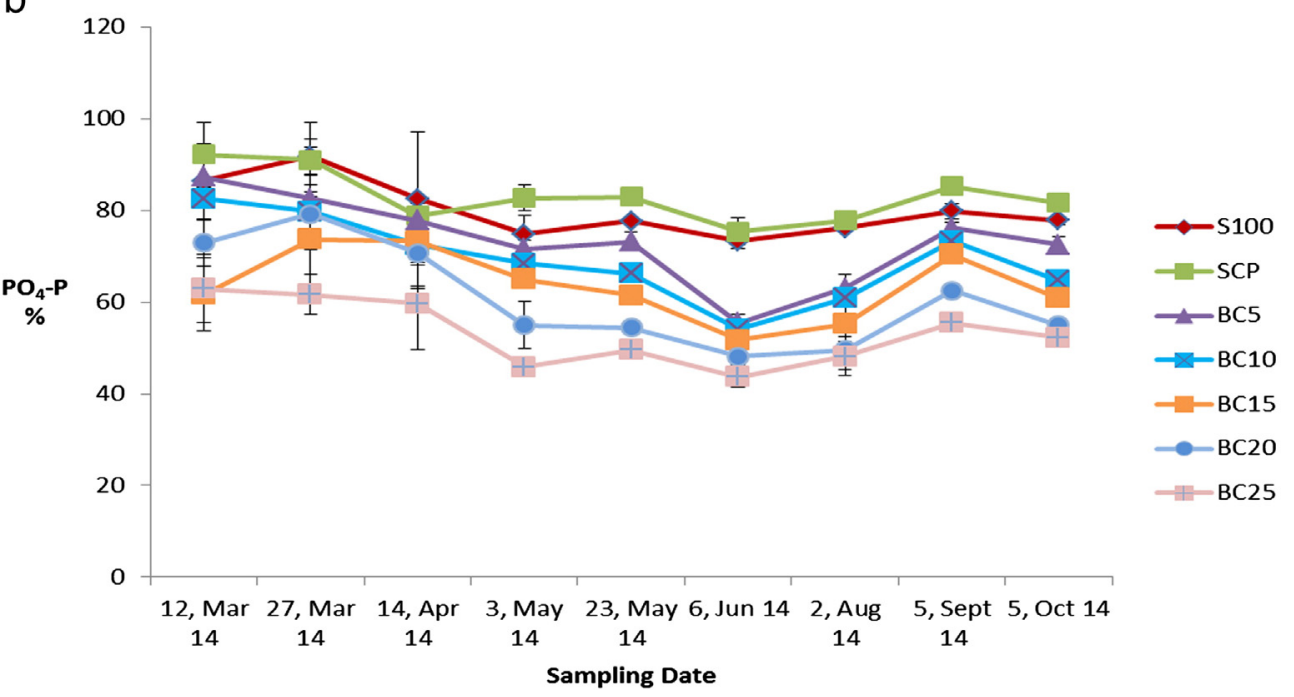

Fig. 3. Percentage (\%) of TP and $\mathrm{PO}_{4}-\mathrm{P}$ removal from secondary clarified wastewater. 
addition of biochar ( $\mathrm{S} 100$ and $\mathrm{SCP}$ ) were lower than that from media containing biochar (BC5, BC10, BC15, BC20 and BC25). The highest outflow concentrations of TP and $\mathrm{PO}_{4}$-P were in the sand media with $25 \%$ of biochar (BC25) meanwhile the lowest outflow concentrations were in the media without addition of biochar (SCP). It was found that, increasing the percentage of biochar in sand media led to increase of TP and $\mathrm{PO}_{4}$-P concentration in the outflows. Based on One-way ANOVA analysis, there were significant differences in $\mathrm{TP}$ and $\mathrm{PO}_{4}-\mathrm{P}$ outflow concentrations among the VF-mesocosm treatments when loaded with SCW (Table 4). Post hoc tests indicated that the performance of TP and $\mathrm{PO}_{4}$ $P$ reduction was significantly better in the media with no addition of biochar.

Fig. 3 shows the removal efficiencies of TP and PO4-P in the seven types of VF mesocosms loaded with secondary clarified wastewater. Removal efficiencies of TP and PO4-P were in the range of 42.1-90.8\% and 43.4-91.7\%, respectively. The highest removal efficiencies were observed in the sand media with no addition of biochar (S100 and SCP) while sand media with $25 \%$ of biochar (BC25) was the poorest performer. This result was in the range obtained by Ayaz et al. (2012) who reported that in the VFCW, the removal efficiency of $\mathrm{PO}_{4}-\mathrm{P}$ from domestic wastewater ranged from 60 to $90 \%$ for the first three months. Ayaz et al. (2012) used gravel, marble stone, zeolite and iron slag as a media and 2.2 days for HRT. In addition, Lucas and Greenway (2010) reported that the cumulative $\mathrm{PO}_{4}-\mathrm{P}$ retention in the turf sand media amended with red mud and Krasnozem soil ranged from $79 \%$ to $95 \%$, whereas the $\mathrm{PO}_{4}-\mathrm{P}$ retention was in the range of 95-99\% for the media amended with water treatment residuals after monitoring for 80 weeks. In this research, $\mathrm{TP}$ and $\mathrm{PO}_{4}$-P removal efficiency was high initially and tended to decrease after loading for several months, indicating the depletion of adsorption sites on the media.

\subsection{TP and $\mathrm{PO}_{4}$-P removal from septage (November 2014-July 2015)}

Fig. 4 shows TP concentrations in the outflow were in the range of 4.8-15.9 mg/L, while for $\mathrm{PO}_{4}-\mathrm{P}$, the outflow concentrations ranged from 4.3 to $14.7 \mathrm{mg} / \mathrm{L}$. From November 2014 to beginning of February 2015 , the trend of outflow concentration in all treatments was increasing. However, between 19 and 21 February 2015, a heavy rain event (190 mm) occurred. After the rain event, the samples taken on 22 February showed a high concentration of both $\mathrm{TP}$ and $\mathrm{PO}_{4}-\mathrm{P}$, ranging from
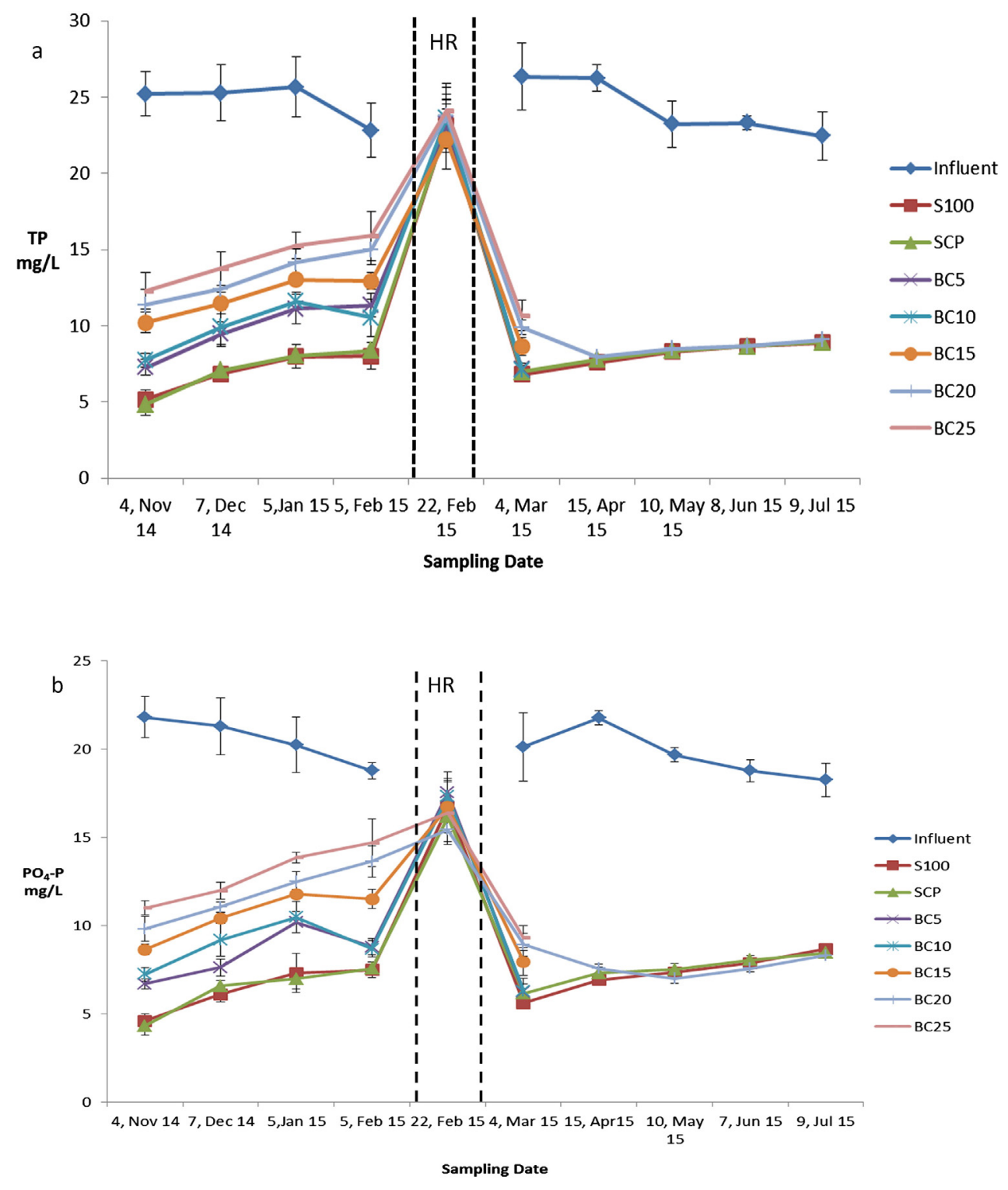

$\mathrm{HR}=$ Heavy rainfall/ flushing event 
Table 5

Significant differences of TP and $\mathrm{PO}_{4}$-P loaded with septage among the treatments $(\alpha<0.05)$.

\begin{tabular}{|c|c|c|c|c|c|c|c|}
\hline & S100 & SCP & BC5 & BC10 & BC15 & BC20 & BC25 \\
\hline $\mathrm{S} 100$ & - & - & - & - & $x+$ & $x+$ & $x+$ \\
\hline SCP & - & - & - & - & $x+$ & $x+$ & $x+$ \\
\hline BC5 & - & - & - & - & - & $x+$ & $x+$ \\
\hline BC10 & - & - & - & - & - & $x+$ & $x+$ \\
\hline BC15 & $x+$ & $x+$ & - & - & - & - & - \\
\hline $\mathrm{BC} 20$ & $x+$ & $x+$ & $x+$ & $x+$ & - & - & - \\
\hline BC25 & $x+$ & $x+$ & $x+$ & $x+$ & - & - & - \\
\hline
\end{tabular}

$\mathrm{x}$ : significant difference of TP $(\alpha<0.05)$.

+ : significant difference of $\mathrm{PO}_{4}-\mathrm{P}(\alpha<0.05)$.

$-:$ no significant differences.

22.2-24.1 $\mathrm{mg} / \mathrm{L}$ and $15.4-17.5$ respectively. This suggested that the rain event may have caused leaching (desorption) of $\mathrm{TP}_{\text {and }} \mathrm{PO}_{4}^{3-}$ from the media. As a result, more binding sites became available. Thus, subsequent samples showed higher phosphorus ( $\mathrm{TP}$ and $\mathrm{PO}_{4}-\mathrm{P}$ ) removal rates. This phenomenon is similar to the "reset mechanisms" described by Lucas and Greenway (2010). Whereby, the outflow concentrations of phosphorus in most treatments decreased after flushing with storm water.

Fig. 4 shows that biochar amended media (BC5, BC10, BC15, BC20 and $\mathrm{BC} 25$ ) had higher outflow concentrations of TP and $\mathrm{PO}_{4}-\mathrm{P}$ compared to the media with no addition of biochar (S100 and SCP). Furthermore, the higher percentage of biochar resulted in the higher TP and

a

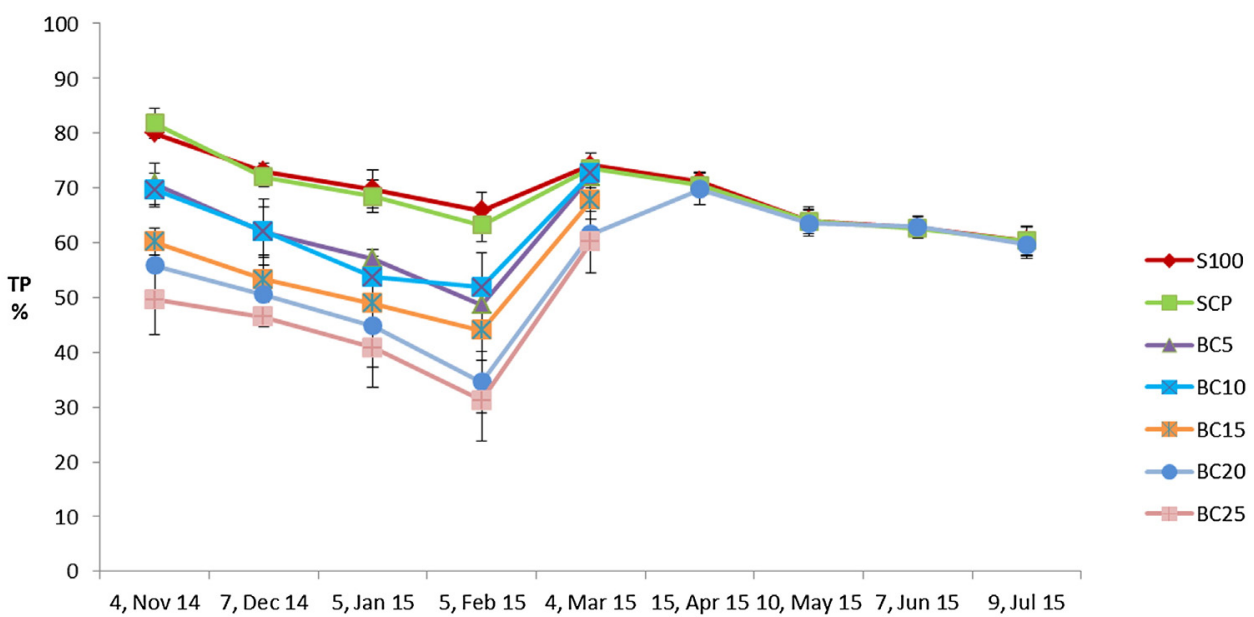

Sampling Date

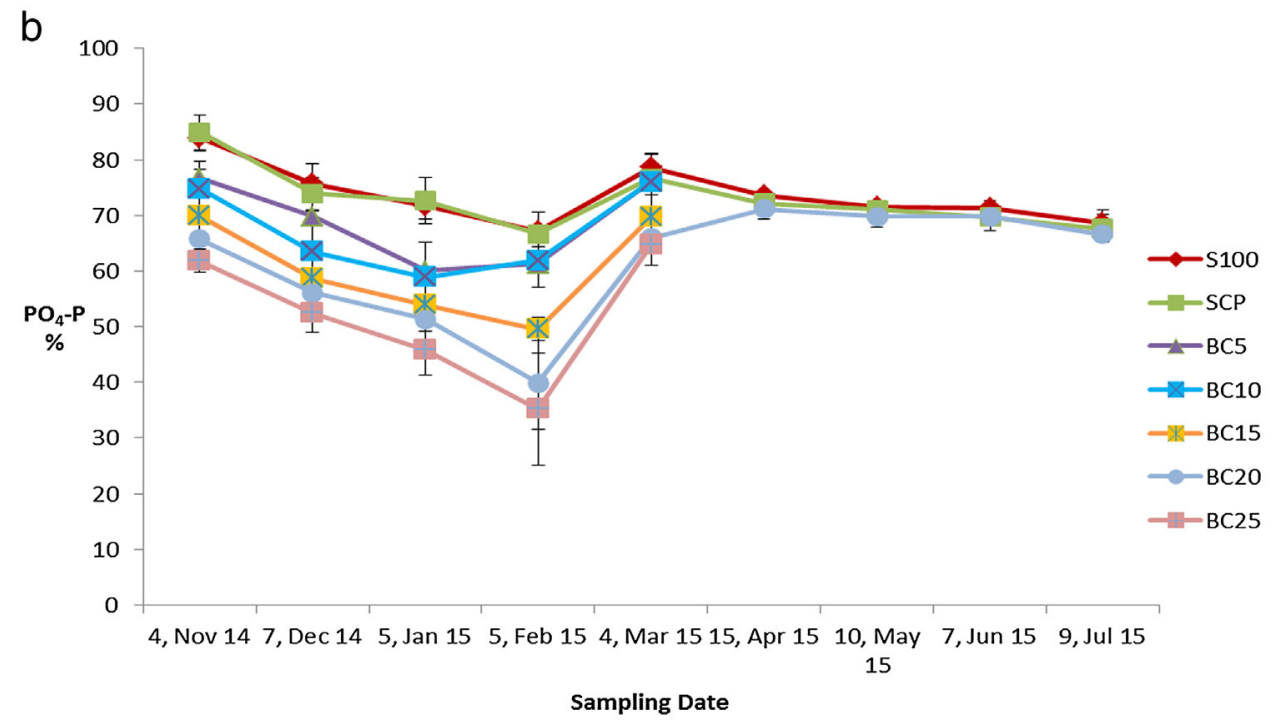

NB: mesocosms for $\mathrm{BC} 5 ; \mathrm{BC} 10 ; \mathrm{BC} 15$; and $\mathrm{BC} 25$ were harvested in March 2015.

Fig. 5. Percentage of $\mathrm{TP}$ and $\mathrm{PO}_{4}$-P removal from septage. NB: mesocosms for $\mathrm{BC} 5$; $\mathrm{BC} 10$; $\mathrm{BC} 15$; and $\mathrm{BC} 25$ were harvested in March 2015. 


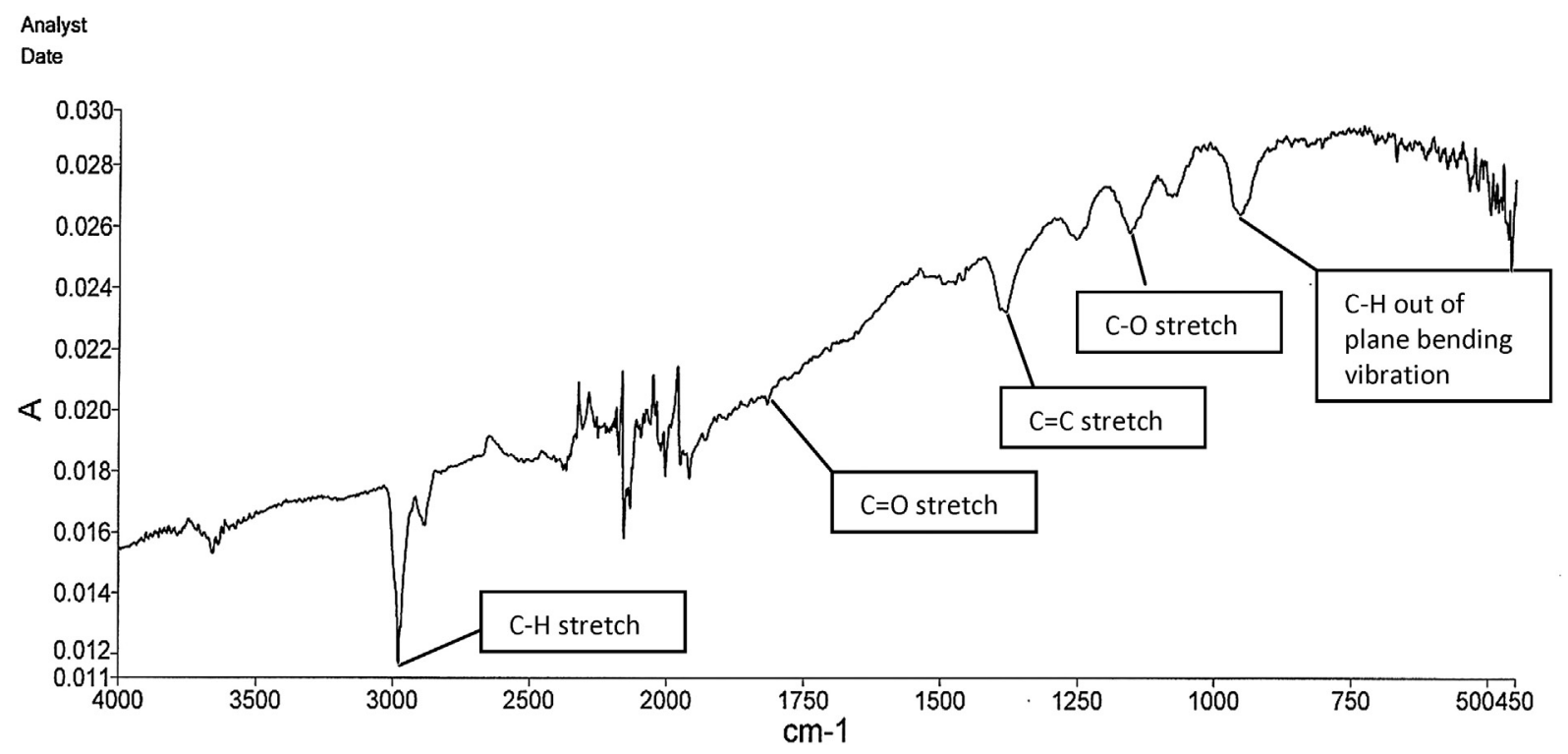

Fig. 6. FTIR spectra of biochar.

$\mathrm{PO}_{4}$-P concentrations in the outflows. Statistical analysis revealed significant differences of TP and $\mathrm{PO}_{4}-\mathrm{P}$ outflows among the VF-mesocosm treatments when loaded with septage. Table 5 shows the matrix of significant differences of TP among treatments.

In the case of the outflow concentration after the heavy rain event (Fig. 4), there was no significant difference between the outflow concentrations of TP and $\mathrm{PO}_{4}-\mathrm{P}$ for the different media. Concentrations of TP and $\mathrm{PO}_{4}-\mathrm{P}$ were 6.8 to $9.1 \mathrm{mg} / \mathrm{L}$ and 5.6 to 8.5 , respectively. Other heavy rain events occurred between the 1st and 3rd April 2015 $(154 \mathrm{~mm})$ and on the 2nd of May 2015 (193 mm) (BOM 2016). This suggested that reset mechanisms also influence the outflow concentrations of phosphorus.

$\mathrm{TP}$ and $\mathrm{PO}_{4}$-P removal efficiencies loaded with septage ranged from 30 to $83 \%$ and $35-85 \%$, respectively (Fig. 5). Sand media (S100 and SCP) had the highest removal efficiency while sand media with $25 \%$ of biochar (BC25) had the lowest removal efficiency. The trend showed that $\mathrm{TP}$ and $\mathrm{PO}_{4}-\mathrm{P}$ removal efficiencies among types of treatments decreased during November 2014 to February 2015 which indicates that the media maybe reaching its $\mathrm{P}$ saturation level. However, the removal efficiency of phosphorus ( $\mathrm{TP}$ and $\mathrm{PO}_{4}-\mathrm{P}$ ) increased for the samples taken in March 2015, following the flushing event due to heavy rain. Removal efficiency of TP and $\mathrm{PO}_{4}$-P collected before (5 February 2015) and after (4 March 2015) heavy rain event were compared using statistical $t$-test and the results showed that there was a significant increase of phosphorus removal efficiency after the flushing event. Although there was no significant difference of TP and $\mathrm{PO}_{4}-\mathrm{P}$ between pure sand media and $\mathrm{BC} 20$, the performance of $\mathrm{BC} 20$ improved and almost reached the removal efficiency of pure sand media after the flushing event. This could be due to more binding sites on media becoming more available. The change of physical and chemical properties of media amended with biochar particularly their binding sites could be the other factor influencing the improvement of removal efficiency by BC20. Furthermore, the rain event may have caused flushing of liquid $C$ compounds from the media thus freeing more adsorption sites for other anions such as phosphates. Cheng et al. (2014) reported that long-term exposure of biochar in the soils had a significant effect on physiochemical structure and sorption properties. Therefore, further research should be conducted to investigate the long term application of sand media amended with biochar in removing phosphorus.

It is revealed that TP and $\mathrm{PO}_{4}-\mathrm{P}$ removal was significantly better in the media with no addition of biochar in both loaded with SCW and septage. This result is in line with the results obtained by Bradley et al. (2015) who reported that increase level of biochar in the sand media increased TP leaching. Bradley et al. (2015) conducted the research with column experiments loaded with dairy manure and used sand media amended with biochar from poplar (Populus maximowiczii) made by a

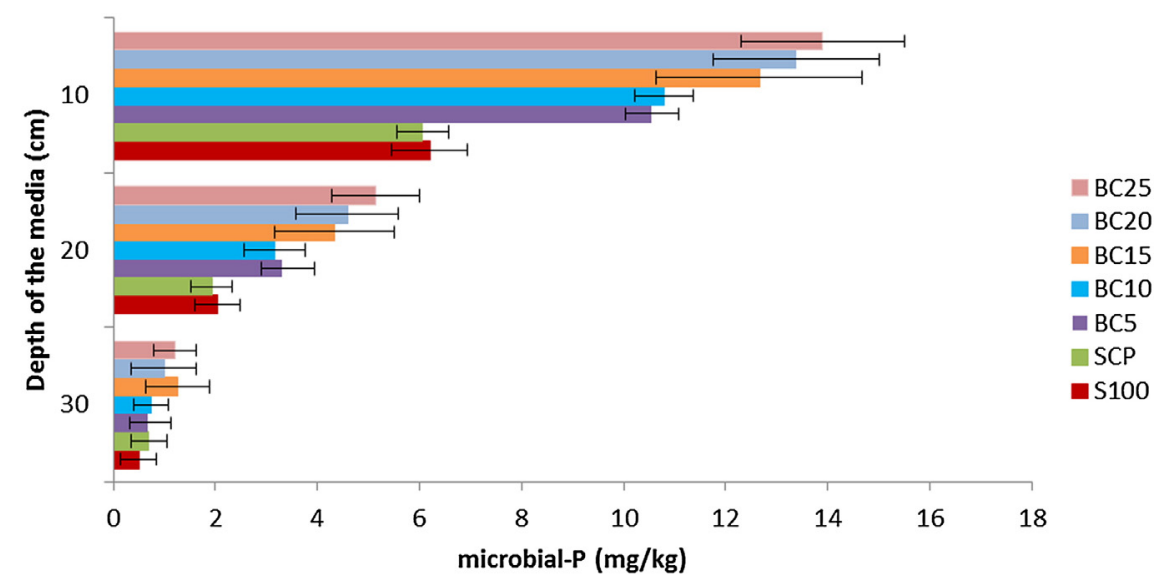

Fig. 7. Abundance of microbial-P (mg/kg) in different depth of seven treatments of VF mesocosms with continuous saturation (August 2014). 
Table 6

Significant differences of microbial P among different depth in each treatment.

\begin{tabular}{|c|c|c|c|c|c|c|c|}
\hline \multirow[b]{2}{*}{ Comparison between depth } & \multicolumn{7}{|l|}{ Media } \\
\hline & S100 & SCP & BC5 & $\mathrm{BC} 10$ & $\mathrm{BC} 15$ & $\mathrm{BC} 20$ & $\mathrm{BC} 25$ \\
\hline $0-10 \mathrm{~cm}$ and $10-20 \mathrm{~cm}$ & $\mathrm{x}$ & $\mathrm{x}$ & $\mathrm{x}$ & $\mathrm{x}$ & $\mathrm{x}$ & $\mathrm{x}$ & $\mathrm{x}$ \\
\hline $0-10 \mathrm{~cm}$ and $20-30 \mathrm{~cm}$ & $\mathrm{x}$ & $\mathrm{x}$ & $\mathrm{x}$ & $\mathrm{x}$ & $\mathrm{x}$ & $\mathrm{x}$ & $\mathrm{x}$ \\
\hline $10-20 \mathrm{~cm}$ and $20-30 \mathrm{~cm}$ & - & - & $\mathrm{x}$ & $\mathrm{x}$ & $\mathrm{x}$ & $\mathrm{x}$ & $\mathrm{x}$ \\
\hline
\end{tabular}

$\mathrm{x}$ : significant difference of microbial $\mathrm{P}(\alpha<0.05)$.

-: no significant differences.

slow pyrolysis process at $450{ }^{\circ} \mathrm{C}$. Sand is dominated by quartz and generally considered as neutral charge (Phillips and Chen 2010). The bonding between sand media and phosphorus could be classified as a loosely bound. Meanwhile biochar generally contains carbon compounds which are rich of electrons. It means that the $\mathrm{PO}_{4}$-P can be leached in both sand and biochar media. In comparison with sand media amended with biochar which imparts electron, $\mathrm{PO}_{4}$-P prefers to bind with pure sand media which mainly has neutral charges.

The phosphorus removal mechanisms that might occur are adsorption and biological (plant and microbes) uptake and precipitation. Adsorption of phosphorus in biochar in the laboratory scales has been reported by several authors (Yao et al. 2011, Chintala et al. 2014, Sarkhot et al. 2013). However, pollutant removal by biochar via adsorption mechanism is not universal depending on several factors; (1) properties of biochar including parent biomass, pyrolysis temperature and residence time, (2) the solution $\mathrm{pH},(3)$ coexisting anions, (4) dosage adsorbent and (5) temperature (Tan et al. 2015). Sarkhot et al. (2013) reported that biochar only adsorbed half of phosphate in manure solution in comparison with phosphate synthetic solution, suggesting competition from other anions for exchange sites on the biochar surface. Yao et al. (2012) reported that biochar had little sorption ability to phosphate and nitrate due to its negative surface charge, allowing the biochar to be more effective at removing cationic species.

In this research, the lower P removal of the sand media amended with biochar in comparison with pure sand media could be due to the chemical composition of both biochar and wastewater. In the sand media amended with biochar, the surface areas of the sand interacted with biochar, thus the addition of biochar in the sand media could influence the soil environment. The higher proportion of biochar in the media increased interaction between biochar particles and the wastewater. In general, biochar surfaces contains carbonyl, carboxylate, hydroxyl, and ether functional groups (Bouchelta et al. 2008). The FTIR spectra of biochar in this research contained stretching in $\mathrm{C}-\mathrm{H}_{2}, \mathrm{C}-\mathrm{O}, \mathrm{C}=\mathrm{O}$ and aromatic $\mathrm{C}-\mathrm{H}$ groups, indicating that the functional groups that existed in the biochar surfaces could be carbonyl, carboxyl, aldehyde, ketones and esters and aromatic (Fig. 6). Carboxyl groups contribute to negative surface charges (Kloss et al. 2012) and these functional groups could play an important role when the biochar interacted with wastewater through Coulombic, dipole and hydrogen bonding. Consequently, presence of these functional groups on the biochar surface could lead to repulsion of negatively charged ions like phosphate.

Anion exchange capacity (AEC) refers to capability of the soil to adsorb exchange anions (Pansu and Gautheyrou 2007). In this research, AEC of the media increased with the increasing of proportion of biochar in sand media. However, AEC existed in the media was small in comparison with its cation exchange capacity (CEC). Thus, phosphate ions persisted in soil solution and were vulnerable to leaching.

Competition with other compounds for exchange sites on the biochar surface is the other factor that should be considered. Tarkalson and Leytem (2009) studied P mobility in sandy loam soil with dairy manure application and suggested that liquid C compound which mainly consisted of carboxyl, phenolic and aromatic ring structure is adsorbed by the soil surface which reduced the ability of the soil to adsorb P. In this research, liquid C compound from SCW and septage could reduce the ability of the media to adsorb phosphorus.

\subsection{Microbial-P}

Microbial P biomass decreased sharply with depth from 6.2$13.9 \mathrm{mg} / \mathrm{kg}$ in the top $0-10 \mathrm{~cm}$ depth to $2.5-5.5 \mathrm{mg} / \mathrm{kg}$ in the $20-$ $30 \mathrm{~cm}$ depth (Fig. 7). Statistical analysis reveals significant differences between microbial activities at different depth in each treatment (Table 6). Similar patterns of microbial biomass decline with the depth were reported by Tietz et al. (2008) who found a rapid decrease of bacterial cells between $1 \mathrm{~cm}$ and $50 \mathrm{~cm}$ depth of the media in three different types of CW systems (planted CW, unplanted, and outdoor $\mathrm{CW}$ ). The higher content of microbial biomass found in the upper $10 \mathrm{~cm}$ layer is attributed to: (1) the vertical loading which provides a higher availability of organic matter, nutrients and oxygen supply which stimulate the growth of microbes (Tietz et al. 2008, Faulwetter et al. 2009) and (2) the filtration process which entrap the bacteria embedded in the solids (Foladori et al. 2015). In this research, the drainage port and tap was located at the bottom of each mesocosm and connected to the outlet which was located $5 \mathrm{~cm}$ below to the height of the media. Since the SCW was loaded continuously, saturated zone occurred approximately in the top $5 \mathrm{~cm}$ of the media. Anaerobic conditions in the deeper parts of the media are likely to prevail. Thereby, the rapid decrease of microbial P biomass could be due to the anaerobic condition and lower nutrient content in the deeper parts of the media.

Microbial P was highest in the media with 25\% of biochar (BC25) and lowest in the media without addition of biochar (S100 and SCP). The data showed that the increase of biochar percentage in the media had an increased microbial-P. This was most pronounced in the $0-10 \mathrm{~cm}$ and $10-20 \mathrm{~cm}$ media depth but there were no significant differences among the media treatments for $20-30 \mathrm{~cm}$ media depth (Table 7). This indicated that the presence of biochar in the sand media encouraged microbial growth particularly in the upper $20 \mathrm{~cm}$. Increase of microbial population in soil amended with biochar has been reported by several authors (Lehmann et al. 2011, Ducey et al. 2015, Xu et al. 2014, Lehmann and Joseph 2012). Microorganisms tend to live in porous structure of the biochar which serve as a habitat to soil microorganism and protect the microorganisms from microarthropods (Gul et al. 2015). In addition, the mesopores and micropores of biochar could store water, dissolved substance and organic matter that are required for microbial metabolisms (Gul et al. 2015, Joseph et al. 2010).

Table 7

Significant differences of microbial P in each depth among different treatments $(\alpha<0.05)$.

\begin{tabular}{llllllll}
\hline & S100 & SCP & BC5 & BC10 & BC15 & BC20 & BC25 \\
\hline S100 & - & - & x & x & x + & x + & x+ \\
SCP & - & - & $\mathrm{x}$ & $\mathrm{x}$ & $\mathrm{x}+$ & $\mathrm{x}+$ & $\mathrm{x}+$ \\
BC5 & $\mathrm{x}$ & $\mathrm{x}$ & - & - & $\mathrm{x}$ & $\mathrm{x}$ & $\mathrm{x}$ \\
BC10 & $\mathrm{x}$ & $\mathrm{x}$ & - & - & - & $\mathrm{x}$ & $\mathrm{x}$ \\
BC15 & $\mathrm{x}+$ & $\mathrm{x}+$ & $\mathrm{x}$ & - & - & - & $\mathrm{x}$ \\
BC20 & $\mathrm{x}+$ & $\mathrm{x}+$ & $\mathrm{x}$ & $\mathrm{x}$ & - & - & - \\
BC25 & $\mathrm{x}+$ & $\mathrm{x}+$ & $\mathrm{x}$ & $\mathrm{x}$ & - & - & - \\
\hline
\end{tabular}

$\mathrm{x}$ : significant difference of microbial $\mathrm{P}$ among treatments in $0-10 \mathrm{~cm}(\alpha<0.05)$.

+ : significant difference of microbial P among treatments in $10-20 \mathrm{~cm}(\alpha<0.05)$.

$\sqrt{ }$ : significant difference of microbial P among treatments in 20-30 cm $(\alpha<0.05)$

- : no significant differences. 
Table 8

Plant biomass P (g P/plant) accumulation harvested in March 2015 (17 months' growth and July 2015 (21 months' growth)

\begin{tabular}{|c|c|c|c|c|c|c|c|}
\hline \multirow[b]{2}{*}{ Plants biomass $\mathrm{P}$} & \multicolumn{7}{|l|}{ Treatment } \\
\hline & S100* & $\mathrm{SCP}^{*}$ & BC5 & $\mathrm{BC} 10$ & BC15 & $\mathrm{BC} 20^{*}$ & $\mathrm{BC} 25$ \\
\hline M. quinquenervia (g P/plant) & $1.55 \pm 0.13^{*}$ & $1.55 \pm 0.07^{*}$ & $0.94 \pm 0.15$ & $1.07 \pm 0.06$ & $1.08 \pm 0.09$ & $1.25 \pm 0.02^{*}$ & $1.15 \pm 0.04$ \\
\hline C. citratus (g P/plant) & $0.55 \pm 0.12^{*}$ & $0.54 \pm 0.12^{*}$ & $0.36 \pm 0.24$ & $0.32 \pm 0.07$ & $0.36 \pm 0.02$ & $0.50 \pm 0.04^{*}$ & $0.40 \pm 0.04$ \\
\hline Total (g P/mesocosm) & $2.10 \pm 0.04^{*}$ & $2.09 \pm 0.14^{*}$ & $1.31 \pm 0.09$ & $1.39 \pm 0.03$ & $1.42 \pm 0.08$ & $1.75 \pm 0.04^{*}$ & $1.55 \pm 0.02$ \\
\hline
\end{tabular}

* : Plant biomass harvested in July 2015

Although the presence of biochar in the sand media had an increased microbial-P, the abundance of microbial-P in the media with high percentage of biochar did not provide a significant contribution of phosphorus removal. Henderson (2008) reported that the rates of microbial uptake of the nutrients were higher than plant uptake. However in comparison to plant uptake, microorganisms do not retain nutrients due to their relatively fragile cell membrane. Thus, the nutrients uptaken by soil microorganisms are rapidly returned to the soils upon cell death (Kadlec and Wallace 2008). This means that microbial uptake is only temporary. Therefore, microorganisms's uptake account for only a small portion of total mass $P$ retained over the period of phosphorus removal. This indicates that plant uptake and adsorption mechanisms play a more significant role of phosphorus removal in constructed wetland mesocosms.

\subsection{Plant uptake}

Uptake of phosphorus by plants is another biological process leading to phosphorus removal in CW eco-technology systems. As inorganic phosphorus is important for plant growth, the amount of phosphorus removed from wastewater can be maximised by selecting appropriate plant species (Greenway 2007). The role of plants in phosphorus removal can be estimated from plant biomass and phosphorus content.

In March 2015 (After 17 months' growth), the bins from four treatments (BC5, BC10, BC15 and $\mathrm{BC} 25)$ were dismantled to harvest both above and below ground of plant biomass. In July 2015, the remaining three treatments (S100, SCP and BC20) were harvested. The plant biomass and phosphorus content in each part of plants were determined. Table 8 shows that the amount of $\mathrm{P}$ ( $\mathrm{g} \mathrm{P} /$ plant) in Melaleuca trees $(M$. quinquenervia) harvested in March and July 2015 ranged from 0.94 (g $\mathrm{P} /$ plant) to 1.15 (g P/plant) and 1.25 (g P/plant) to 1.55 (g P/plant), respectively. The biomass $P$ in lemongrass (C. citratus) was in the range of 0.32-0.40 (g P/plant) in March 2015 and from 0.50-0.55 (g P/plant) in July 2015. The total $P$ biomass in each treatment harvested in March 2015 and July 2015 were in the range of 1.31-1.55 ( $\mathrm{g} \mathrm{P} /$ mesocosm) and $1.75-2.10$ ( $\mathrm{g}$ P/mesocosm), respectively. Statistical analysis showed that there was no significant difference of Melaleuca P biomass among the treatments plants harvested in March 2015. However, for the P biomass harvested in July 2015, the One-way ANOVA test showed sand media with no addition of biochar was significantly higher than the sand media amended with $20 \%$ of biochar. For the lemongrass, the ANOVA test showed that there were no significant differences for the P biomass both harvested in March and July 2015. This indicated that plant growth particularly Melaleuca trees in pure sand media play a significant role for phosphorus removal in comparison with the sand media amended with $20 \%$ of biochar. The results of biomass P in Melaleuca trees (M. quinquenervia) were comparable with the results reported by Bolton and Greenway (1997) who reported total biomass P in M. quinquenervia was $1.42 \mathrm{~g} \mathrm{P} /$ plant after 21 months of growth in sand media but higher than the result reported by Greenway (2013) who revealed that $\mathrm{P}$ biomass of Melaleuca planted in the media contained $80 \%$ of sand and $20 \%$ water treatment residuals (WTR) was $0.95 \mathrm{~g}$ P over 2 years. The results of biomass $P$ in lemongrass ( $C$. citratus) was similar to the result of $\mathrm{P}$ biomass in Vetiver (Chrysopogon zianioides) in the media with $80 \%$ of sand and $20 \%$ water treatment residuals (WTR) as a reported by Greenway (2013). The author reported that P biomass in C. zianioides was $0.45 \mathrm{~g}$ P per plant over 12 months. To assess the importance of plants in removing nutrients, the maximum capacity of plant to store nutrients should be considered (Greenway 2007).

\section{Conclusion}

In vertical flow constructed wetland mesocosms, the results showed that sand media amended with biochar was less effective in removing $\mathrm{TP}$ and $\mathrm{PO}_{4}-\mathrm{P}$ from secondary treated wastewater and septage. The removal efficiency of TP and $\mathrm{PO}_{4}$-P were inversely related to the biochar content in the sand media. Microbial P biomass in the media declined with depth, with highest microbial-P activities found to take place in the upper $20 \mathrm{~cm}$ of media for all cases. Nevertheless, higher microbial $P$ biomass was found in sand amended with biochar suggesting that the presence of biochar encouraged microbial activity. Microbial-P biomass did not provide a significant contribution to phosphorus removal. Total plant biomass $\mathrm{P}$ ( $\mathrm{g} \mathrm{P} /$ plant) in plants grown in sand amended with biochar was significantly lower than those grown in sand alone. Overall, for phosphorus removal from wastewater, the results suggested that biochar augmented sand media is less effective substrate media for vertical flow subsurface constructed wetlands. However, more research is needed to investigate other types of biochar and potential chemical or physical treatments to improve the biochar performance as media amendment in constructed wetlands.

\section{Acknowledgement}

Philiphi de Rozari is a recipient of Australian Development Scholarship (ADS) PhD scholarship. The research was conducted at the Loganholme Water Pollution Control Centre and the authors would like to acknowledge Steve Walter and the rest of the staff at Loganholme Water Pollution Control Centre for their kind cooperation. Special thanks are also given to Scott Byrnes and James Canon for their assistance in chemical analysis.

\section{References}

Abou-Elela, S.I., Golinielli, G., Abou-Taleb, E.M., Hellal, M.S., 2013. Municipal wastewater treatment in horizontal and vertical flows constructed wetlands. Ecol. Eng. 61, $460-468$.

APHA, 2005. Standard methods for the examination of water and wastewater, Washington DC, USA.

Arias, C., Del Bubba, M., Brix, H., 2001. Phosphorus removal by sands for use as media in subsurface flow constructed reed beds. Water Res. 35, 1159-1168.

Ayaz, S.Ç., Aktas, Ö., Findik, N., Akca, L., 2012. Phosphorus removal and effect of adsorbent type in a constructed wetland system. Desalin. Water Treat. 37, 152-159.

Bolton, K.G., Greenway, M., 1997. A feasibility study of Melaleuca trees for use in constructed wetlands in subtropical Australia. Water Sci. Technol. 35, 247-254.

BOM, 2016. Rainfall and temperature Records for Loganholme Water Treatment Plant Retrieved: http://www.bom.gov.au/climate/data/index.shtml?bookmark=200.

Bouchelta, C., Medjram, M.S., Bertrand, O., Bellat, J.P., 2008. Preparation and characterization of activated carbon from date stones by physical activation with steam. J. Anal Appl. Pyrolysis 82, 70-77.

Bradley, A., Larson, R., Runge, T., 2015. Effect of wood biochar in manure-applied sand columns on leachate quality. J. Environ. Qual. 44, 1720-1728.

Brookes, P., Powlson, D., Jenkinson, D., 1982. Measurement of microbial biomass phosphorus in soil. Soil Biol. Biochem. 14, 319-329.

Cheng, C.H., Lin, T.P., Lehmann, J., Fang, L.J., Yang, Y.W., Menyailo, O.V., Chang, K.H., Lai, J.S., 2014. Sorption properties for black carbon (wood char) after long term exposure in soils. Org. Geochem. 70, 53-61. 
Chintala, R., Schumacher, T.E., McDonald, L.M., Clay, D.E., Malo, D.D., Papiernik, S.K., Clay, S.A., Julson, J.L., 2014. Phosphorus sorption and availability from biochars and soil/ biochar mixtures. CLEAN-Soil Air Water 42, 626-634.

De Rozari, P., Greenway, M., El Hanandeh, A., 2015. An investigation into the effectiveness of sand media amended with biochar to remove BOD5, suspended solids and coliforms using wetland mesocosms. Water Sci. Technol. 71, 1536-1544.

Ducey, T.F., Novak, J.M., Johnson, M.G., 2015. Effects of biochar blends on microbial community composition in two coastal plain soils. Agriculture 5, 1060-1075.

Ekpenyong, C.E., Akpan, E., Nyoh, A., 2015. Ethnopharmacology, phytochemistry, and biological activities of Cymbopogon citratus (DC.) Stapf extracts. Chin J. Nat. Med. 13 321-337.

Faulwetter, J.L., Gagnon, V., Sunberg, C., Chazarenc, F., Burr, M.D., Brisson, J., Camper, A.K. Stein, O.R., 2009. Microbial processes influencing performance of treatment wetlands: a review. Ecol. Eng. 35, 987-1004.

Foladori, P., Bruni, L., Tamburini, S., 2015. Bacteria viability and decay in water and soil of vertical subsurface flow constructed wetlands. Ecol. Eng. 82, 49-56.

Greenway, M., 2007. The role of macrophytes in nutrient removal using constructed wetlands. In: Singh, S.N., Tripathi, R.D. (Eds.), Environmental bioremediation technologies. Springer, Lucknow, pp. 331-345.

Greenway, M., 2013. A decade of bioretention research. Proceeding of 8th International Water Sensitive Urban Design Conference. November 2013, Surfers Paradise Gold Coast, Australia. Water Sensitive Urban Design Publishing, Gold Coast, Australia, pp. 21-31.

Gul, S., Whalen, J.K., Thomas, B.W., Sachdeva, V., Deng, H., 2015. Physico-chemical properties and microbial responses in biochar-amended soils: mechanisms and future directions. Agric. Ecosyst. Environ. 206, 46-59.

Gupta, P., Ann, T.W., Lee, S.M., 2015. Use of biochar to enhance constructed wetland performance in wastewater reclamation. Environ. Eng. Res. 21, 36-44.

Henderson, C.F.K., 2008. The chemical and biological mechanisms of nutrient removal from stormwater in bioretention systems. Griffith University, Brisbane.

Hossain, M.K., Strezov, V., Chan, K.Y., Ziolkowski, A., Nelson, P.F., 2011. Influence of pyrolysis temperature on production and nutrient properties of wastewater sludge biochar. J. Environ. Manag. 92, 223-228.

Joseph, S., Camps-Arbestain, M., Lin, Y., Munroe, P., Chia, C., Hook, J., Van Zwieten, L., Kimber, S., Cowie, A., Singh, B., 2010. An investigation into the reactions of biochar in soil. Soil Res. 48, 501-515.

Kadlec, R.H., Wallace, S., 2008. Treatment wetlands. CRC press, Boca Raton.

Kloss, S., Zehetner, F., Dellantonio, A., Hamid, R., Ottner, F., Liedtke, V., Schwanninger, M. Gerzabek, M.H., Soja, G., 2012. Characterization of slow pyrolysis biochars: effects of feedstocks and pyrolysis temperature on biochar properties. J. Environ. Qual. 41, 990-1000.

Kurniadie, D., 2011. Wastewater treatment using vertical subsurface flow constructed wetland in Indonesia. Am. J. Environ. Sci. 7 (1), 15-19.
Lehmann, J., Joseph, S., 2012. Biochar for environmental management: science and technology. Routledge, Oxon.

Lehmann, J., Rillig, M.C., Thies, J., Masiello, C.A., Hockaday, W.C., Crowley, D., 2011. Biochar effects on soil biota-a review. Soil Biol. Biochem. 43, 1812-1836.

Lucas, W.C., Greenway, M., 2010. Phosphorus retention by bioretention mesocosms using media formulated for phosphorus sorption: response to accelerated loads. J. Irrig. Drain. Eng. 137, 144-153.

Manya, J.J., 2012. Pyrolysis for biochar purposes: a review to establish current knowledge gaps and research needs. Environ. Sci. Eng. 46, 7939-7954.

Matejovic, I., Durackova, A., 1994. Comparison of microwave digestion, wet and dry mineralization, and solubilization of plant sample for determination of calcium, magnesium, potassium, phosphorus, sodium, iron, zinc, copper, and manganese. Commun. Soil Sci. Plant Anal. 25, 1277-1288.

Pansu, M., Gautheyrou, J., 2007. Handbook of soil analysis: mineralogical, organic and inorganic methods. Springer Science \& Business Media, New York.

Phillips, I., Chen, C., 2010. Surface charge characteristics and sorption properties of bauxite-processing residue sand. Soil Res. 48, 77-87.

Sarkhot, D., Ghezzehei, T., Berhe, A., 2013. Effectiveness of biochar for sorption of ammonium and phosphate from dairy effluent. J. Environ. Qual. 42, 1545-1554.

Tan, X., Liu, Y., Zeng, G., Wang, X., Hu, X., Gu, Y., Yang, Z., 2015. Application of biochar for the removal of pollutants from aqueous solutions. Chemosphere 125, 70-85.

Tarkalson, D.D., Leytem, A.B., 2009. Phosphorus mobility in soil columns treated with dairy manures and commercial fertilizer. Soil Sci. 174, 73-80.

Tietz, A., Langergraber, G., Watzinger, A., Haberl, R., Kirschner, A.K., 2008. Bacterial carbon utilization in vertical subsurface flow constructed wetlands. Water Res. 42, 1622-1634.

Vohla, C., Koiv, M., Bavor, H.J., Chazarenc, F., Mander, Ü., 2011. Filter materials for phosphorus removal from wastewater in treatment wetlands-a review. Ecol. Eng. 37, 70-89.

Wanyama, J., Herremans, K., Maetens, W., Isabirye, M., Kahimba, F., Kimaro, D., Poesen, J., Deckers, J., 2012. Effectiveness of tropical grass species as sediment filters in the riparian zone of Lake Victoria. Soil Use Manag. 28, 409-418.

Westholm, L.J., 2006. Substrates for phosphorus removal-potential benefits for on-site wastewater treatment? Water Res. 40, 23-36.

Xu, H.J., Wang, X.H., Li, H., Yao, H.Y., Su, J.Q., Zhu, Y.G., 2014. Biochar impacts soil microbial community composition and nitrogen cycling in an acidic soil planted with rape. Environ. Sci. Technol. 48, 9391-9399.

Yao, Y., Gao, B., Inyang, M., Zimmerman, A.R., Cao, X., Pullammanappallil, P., Yang, L., 2011. Biochar derived from anaerobically digested sugar beet tailings: characterization and phosphate removal potential. Bioresour. Technol. 102, 6273-6278.

Yao, Y., Gao, B., Zhang, M., Inyang, M., Zimmerman, A.R., 2012. Effect of biochar amendment on sorption and leaching of nitrate, ammonium, and phosphate in a sandy soil. Chemosphere 89, 1467-1471. 